\title{
生研試作アルミ的廷について
}

\section{ON THE IIS ALUMINUM BOAT BUILT FOR TRIAL}

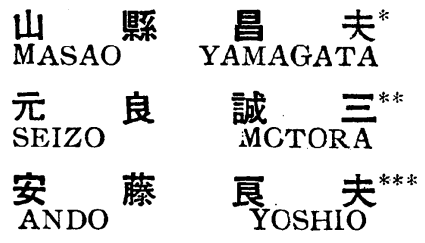

We built a boat with out-board engine for trial from light alloy 56S. The following data is ofintersest : L.O.A. $5.000 \mathrm{~m}$; beam $1.486 \mathrm{~m}$; depth $0.678 \mathrm{~m}$; weight of hull only, $100 \mathrm{~kg}$. This weightis about a half compared with the same type wooden one.

In future sails will be fitted.; The form of the boat is suitable for motor boat trimming by the stern and is suitable for yacht when the boat is even keel except engine.

The maximum speed was 27 knots with $22 \mathrm{~F}$ out-board engine.

This boat has been and will be used to study work, strength, vibration, corrosion etc.

\section{1. 緒 言}

船船の Dead Weight (載賲重量) に対して Light Weight（自重と考えてよい）を軽くしようとする努力 は終止続けられている。工作法の面からは鋲構造から熔 接構造へと移つたが，構造材㩽の面からは木から鉄，鉄 から鋼と変つで来た。そして近年姿をあらおしてきたの がアルミ合金でする。

歐米に扔いてはこの種の合金は船体構造の一部に盛に 使われ，第二次大戦以後建造された大型客船では大量の アルミ合金を使用してているものが多い。

わが国に打いでもアルミ合金を船に応用しようとする 気運か熟し，使用される量は必ずしも多くたいが，昭和 25年石川自造船所て建造された保安庁の巡視船大王以来 多数の船の上部棈造, 䑶装品, 救命艇などに使用されて 来た。

著者等は䑤用アルミニウム合金のらち耐蝕性打よび強 度はすぐれているが，工作か困難といれれる第二種半硬 質 (56 S-x $/ 2 \mathrm{H})$ を用いて長さ約 $5 \mathrm{~m} \sigma$ 全軽会金製のヨッ 卜兼舷外機艇を設哔試作し，工作法，強度，振動，耐蝕 性の研究をはじめたが，一応舷外機艇としての工事は完 了したのでそれまでをとりまとめたのが本報告である。

\section{2. 艇型}

試作艇の一般配置を筙 1 図に示す。艇尾に50HJohns on Seahorse舷外機をつけ約30ノットて航走するように すると共に，舷外機を外して帆をつければョットとしで も使用できるようSnipe型の帆装具も備えている。

軽合金製艇では梞製艇と異り構造材自体の浮力ふ殆と たいので万一損傷した場合には沈沒の危険があるのでコ ツクピツト前部と後部に約 $412 \mathrm{~kg}$ の浮力を有する空気箱 をそなえて浮出タンクとしている。

試作艇は前述の如くモーターボートとヨットと両方の 目的に使用されるので艇型に王夫がこらされた。すたお ちヨットでは最大速力8ノット程度でするのに舷外機艇 としつは約30ノットに達し，前者では艇尾の巾か狭く水 線型が滑かなものがよく，後者に対しては艇尾の巾が広 く底面全体が滑定板となるようた型がよいからである。 そこで舷外機を艇尾につけるためのトリム(傾斜)に よつてこの三つの相異る艇型を使いわけることとした。 本艇を1mトリムさせるに要するモーメントは1.107 t-m で，マストをとり舷外機をつけると紎0.25mのトリムを 生ずる。それ故第 2 図のように帆走時に汪ぼeven keel でョットの艇型となり，船外機をつけた時には0.25mト

* 東京大学工学部教授工学博士

Prof., Faculty of Engineering, University of Tokyo.

** 東京大学工学部助教授

A. Prof.,Faculty of Engineering, University of Tokyo.

*** 東京大学生産技術研究所助教授

A. Prof., Institute of Industrial Science, University of Tokyo. 

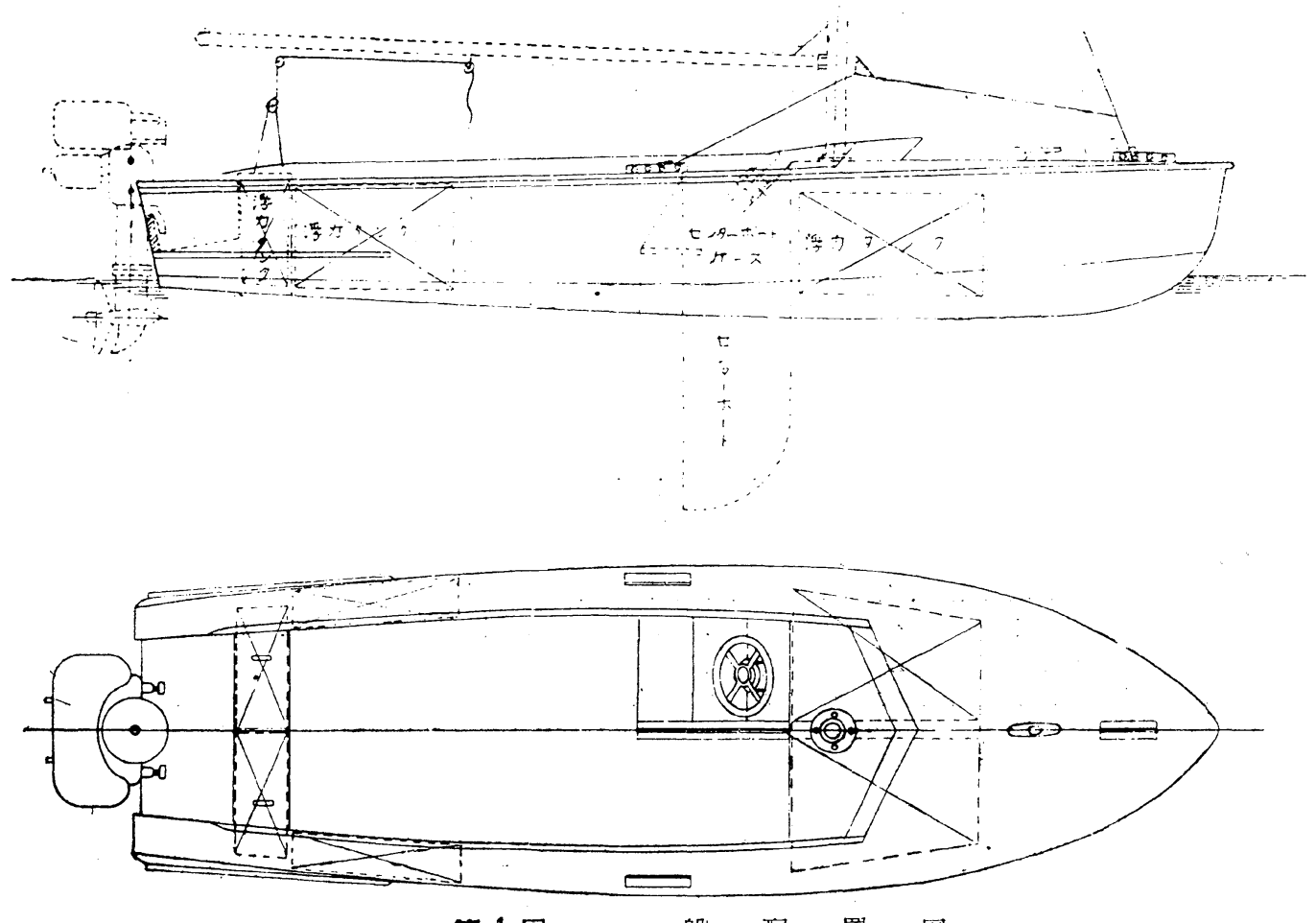

第1図一般配置図

Fig. 1 General arrangement
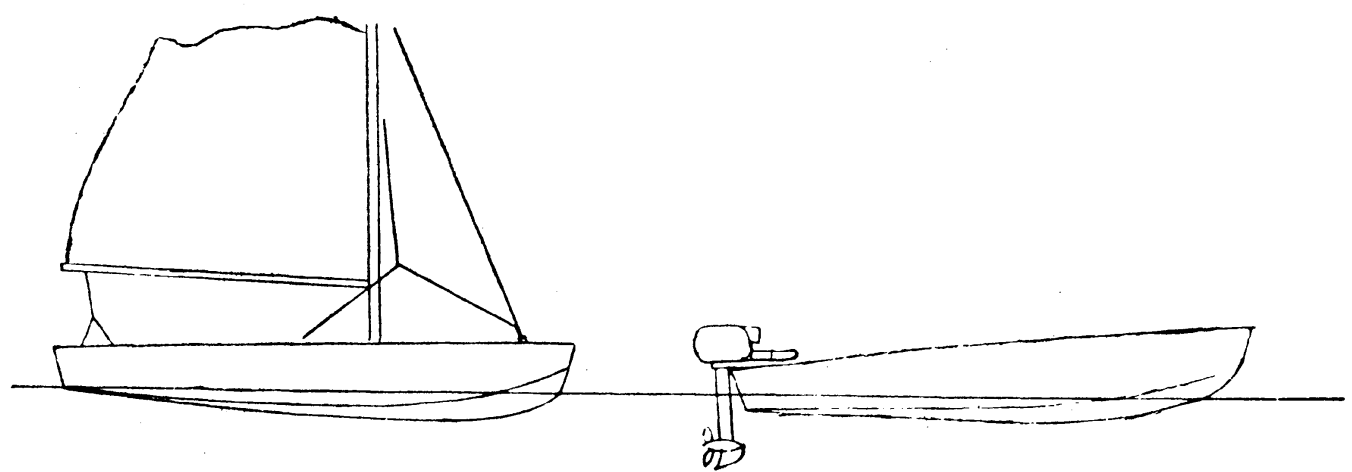

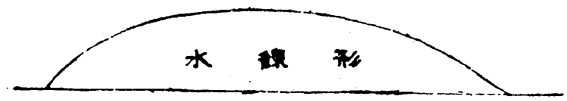

走的

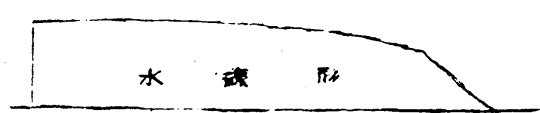

枓策

第 2 図 Fig. 2

リムして活涪高速艇の艇型に近くなるよう線図を定めた その艇型の線四を第 3 図に示す。

た扔高速時に挺尾が過度に沈下するのを防ぐために艇 尾のchine line“を下向きの四線とし，その揚力によつて
航走時の姿势を保ちうるようにした。 試作艇の主要要目は次の通りである。
全 長
$5.000 \mathrm{~m}$
巾
1. $486 \mathrm{~m}$ 

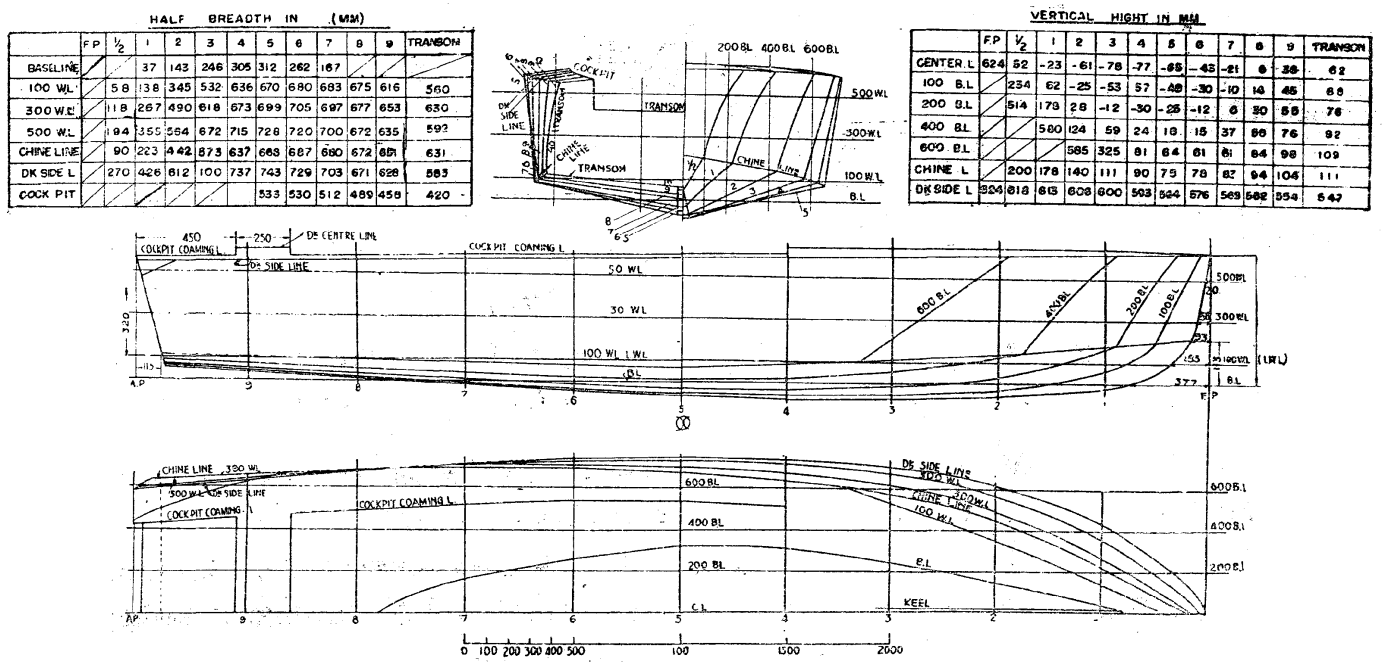

第 3 図線図

Fig. 3 Lines

深.さ

計画排水量

$0.678 \mathrm{~m}$

$389 \mathrm{~kg}$ (帆济更び乘員3名共)

\section{3. 强度}

軽合金を使用するとき惊製艇ては問題とならない個 所の挫屈等も十分考慮して設語する必要が岁る。

艇首艇底に衝慗をらけた場合が縦強度上最も大たる荷 重と考えられるので只の計算例を示す。

$\mathrm{P}=$ - $\mathrm{nW}$ WすがFPよりL/6の所に仂くとする。W は満載排水量，几は荷重倍数で2.Qにとつた。重心を通 る軸の周りの犋量の慣性モーメントを. I, 慙心から $\mathrm{P}$ での距﨎をととし，浮うは無視する。(第4図参照)実際

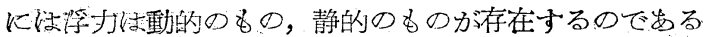
が，これを考慮すれば荷重汃減るので無視しても安全側

にでる。重心の上向の線加速度は

$$
\ddot{z}_{1}=\frac{\mathrm{P}}{\mathrm{W} \cdot \mathrm{g}}
$$

但し g隹重力口加速度

重心の周りの角加速度位

$$
\ddot{\theta}=\frac{\mathrm{eP}}{1}
$$

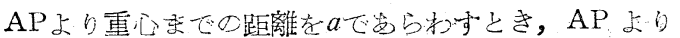

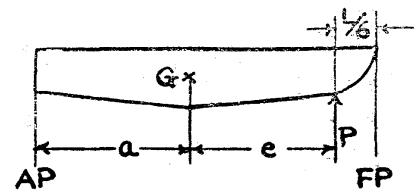

第 4 図 Fig. 4 $x$ なる点の綜合線加速度这次のようになる。

$$
\ddot{z}=\ddot{z}_{1}+(x-a) \ddot{\theta}
$$

Weight curve $\mathrm{w}(x)$ とすれば Load curve $\mathrm{L}(\boldsymbol{x})$ は $w(x) \ddot{z} / g$ 分布荷重の㴽か $x=5 \mathrm{~L} / 6$ に集中荷重 $\mathrm{P}$ が 仂 $<$ 。

Shearing Forth curvel $\mathrm{F}(\boldsymbol{x})=\int \mathrm{L}(\boldsymbol{x}) \mathrm{dx}$, Bending Moment curvel $\mathrm{M}(x)=\int \mathrm{F}(x) \mathrm{dx}$ によりそれぞれ求 められる。

試作艇の設計に蹬しては
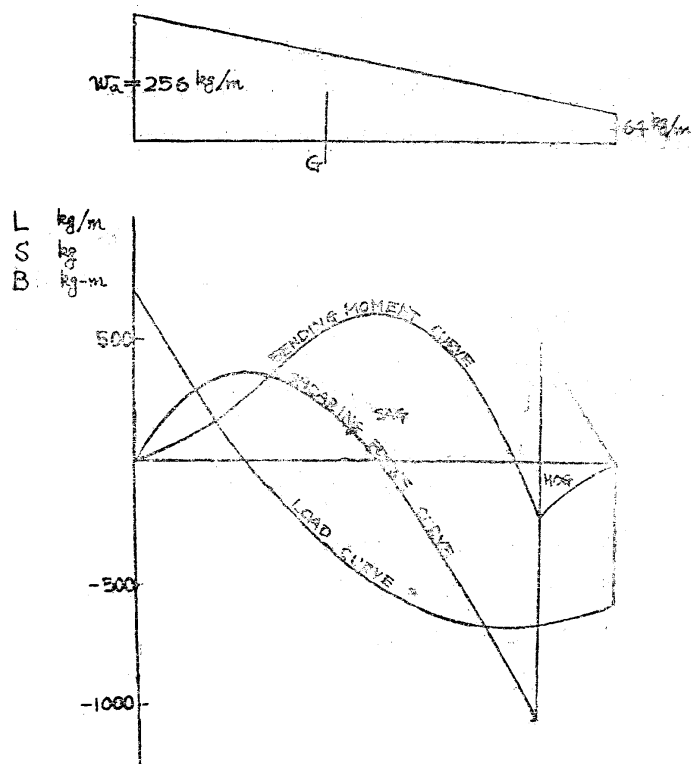

第 5 図 Fig. 5 


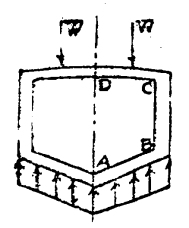

10

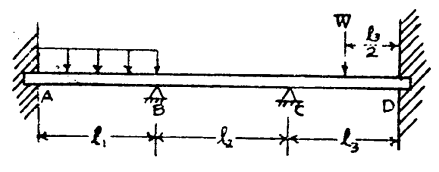

(b)
$\mathbf{W}=800 \mathrm{~kg}$

重心 $0.5 \mathrm{~m}$ abaft $a=2.0 \mathrm{~m}$

$\mathrm{L}=5.00 \mathrm{~m}$

艇の重量は linearに分布すると考えれば $W_{a}=256 \mathrm{~kg} /$ $\mathrm{m}, W_{f}=64 \mathrm{~kg} / \mathrm{m}$ となる。

Weight, Load, Shearing Force, Bending Moment curvest第 5 図に示市。

$$
\begin{array}{lll}
F_{\text {max }}=1,064 \mathrm{~kg} \quad \text { at } & \mathrm{x}=4.17 \mathrm{~m} \\
M_{\text {max }}=623 \mathrm{~kg}-\mathrm{m}(\mathrm{sag}) \text { at } & \mathrm{x}=2.51 \mathrm{~m}
\end{array}
$$

両端を妾持した長さLの梁の中央に集中荷重がもる場 合の Bending Moment の最大值は界WL, 同し荷重が 一様に分布した場合は $1 / 8 \mathrm{WL}$, Shearing Force の最大 值は何れの場合もW/2である。木製のヨットの場合はこ の中間をとつて产WLで就計する場合が多いようである が，前述の数值を入れると

$$
\begin{aligned}
& \mathrm{F}_{\max }=400 \mathrm{~kg} \\
& \mathrm{M}_{\max }=667 \mathrm{~kg}-\mathrm{m}
\end{aligned}
$$

とたり, 前部衝慗の場合にくらべととending Nomen ${ }_{t}$ は柱闰じであるのに反し, Shearing Force は非常な 違いでむる。木製艇では部材の厚さか非常に大きいので Shearing Forcekよる挫屈は考える必要はないが，軽 合金製の艇では間題になる。

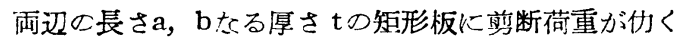
場合の挫屈応力は

$$
\begin{gathered}
\tau_{c r}=\mathrm{k}\left\{\mathrm{E} /\left(1-\frac{1}{\mathrm{~m}^{2}}\right)\right\}(\mathrm{t} / \mathrm{b})^{2} \\
\text { 但し } \mathrm{E}: \text { } 1 \text { ヤンク率 } \\
\mathrm{m}: \text { ポアソン数 } \\
\mathrm{k}: \text { 係数 }
\end{gathered}
$$

試作艇に怙いでは $\mathrm{b}=155 \mathrm{~mm}, \mathrm{k}=5.02\left(\mathrm{a} / \mathrm{b}=3.0\right.$, 四辺交持) て $\tau_{c} r=$ $\mathrm{kg} / \mathrm{mm}^{2}$ とたる。第5 図でかかるよらに最大焋断力はFP よりL/6k扢こり，その位置の最大剪断応力は

$$
\tau_{\max }=1.00 \mathrm{~kg} / \mathrm{mm}^{2}
$$

でむる。これはshear resistanceでもつ場合で,これで

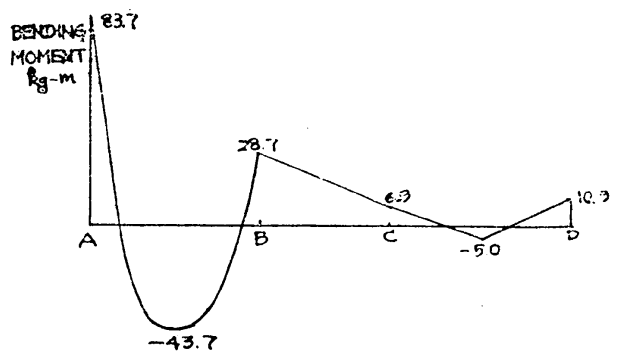

Fig. 7

挫屈しても造とは tension field でもつから安全率住任 ぼ1で小さくして娄る。

次に横強度C゙あるが第 6 图 (a) の如き艇体の朐材は中 心線より切断して (b) の如く引伸した両端固定の連続梁 に怙きかえて諳算を行つた。

一例としてFr. No.5についで行つた計算結果を示す。

$$
\left\{\begin{array}{l}
1_{1}=660 \mathrm{~mm}, 1:=520 \mathrm{~mm}, 1_{3}=740 \mathrm{~mm} \\
w=(f \mathrm{r} \cdot \mathrm{sp}) \times \mathrm{p}=18 \mathrm{~kg} / \mathrm{cm} \\
\mathrm{p}=0.3 \mathrm{~kg} / \mathrm{cm}^{2} \\
\mathrm{~W}=75 \mathrm{~kg}
\end{array}\right.
$$

以上の数值を入れてBending Monent を計算すると第 7困のようになる。肋材の梁さは縦通材が貫通すること をも考慮して上記の Bending Momentに対して十分に 設計を行つた。肋骨は重量節約のため一枚の板から切り ぬいて造り，緃通材を joggle して肋材の flangeは切 らず強度の低下を防いだが，工作が面倒にたつた。

水王 $\mathrm{p}$ をちける艇底外板は肋材と縌通材に囲れた大体 矩形の形をるち，そのアスペクト比は 3 以上でむるので 对辺固定の無限带板之考える。 (第 8 四)

$$
2 \mathrm{a} / \mathrm{t}=\mu
$$

と扔くと最大曲げ応力は固定縁 にて

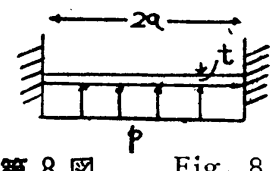

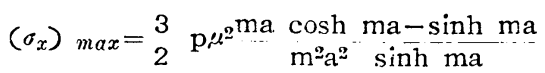

弓張応力は

$$
\begin{aligned}
& \bar{\sigma}_{x}=\begin{array}{c}
\mathrm{E} \mathrm{m}^{2} \mathrm{a}^{2} \\
3\left(1-\gamma^{2}\right) \mu^{2}
\end{array} \\
& \text { 但し } \mathrm{E}+\text { ヤ゙率 } \\
& \gamma \text { ポアソン比 }
\end{aligned}
$$

maは次式より求まる。

$$
\begin{aligned}
& \sqrt{\frac{8}{27}\left(1-\gamma^{2}\right)^{3 / 2} \mu^{4} \mathrm{p}}=\frac{1}{\mathrm{~m}^{3} \mathrm{a}^{3}}\left(\frac{1}{3}+\frac{2}{\mathrm{~m}^{2} \mathrm{a}^{2}}-2 \sinh =\frac{1}{\mathrm{ma}}\right. \\
& \left.-\frac{3 \cosh \mathrm{ma}}{2 \operatorname{masinh} \mathrm{ma}}\right)^{\mathrm{x} / 2} \\
& \text { 板の最大応力は } \\
& \sigma_{\max }=\left(\sigma_{x}\right)_{\max }+\bar{\sigma}_{x}
\end{aligned}
$$




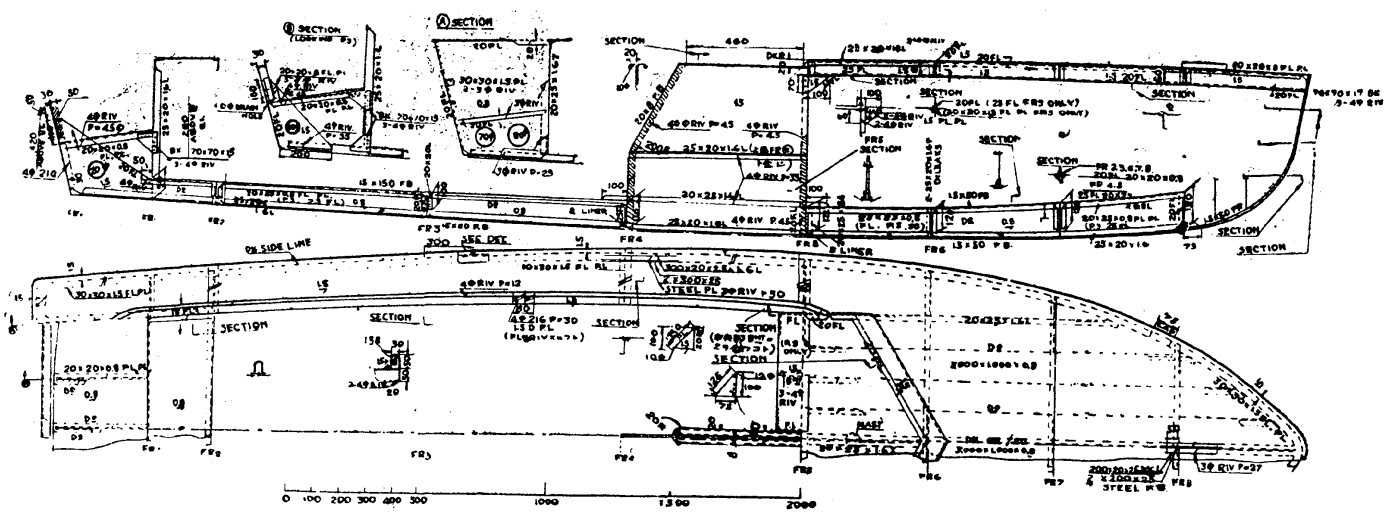

第 9 図構造図

Fig. 9 Construction profile
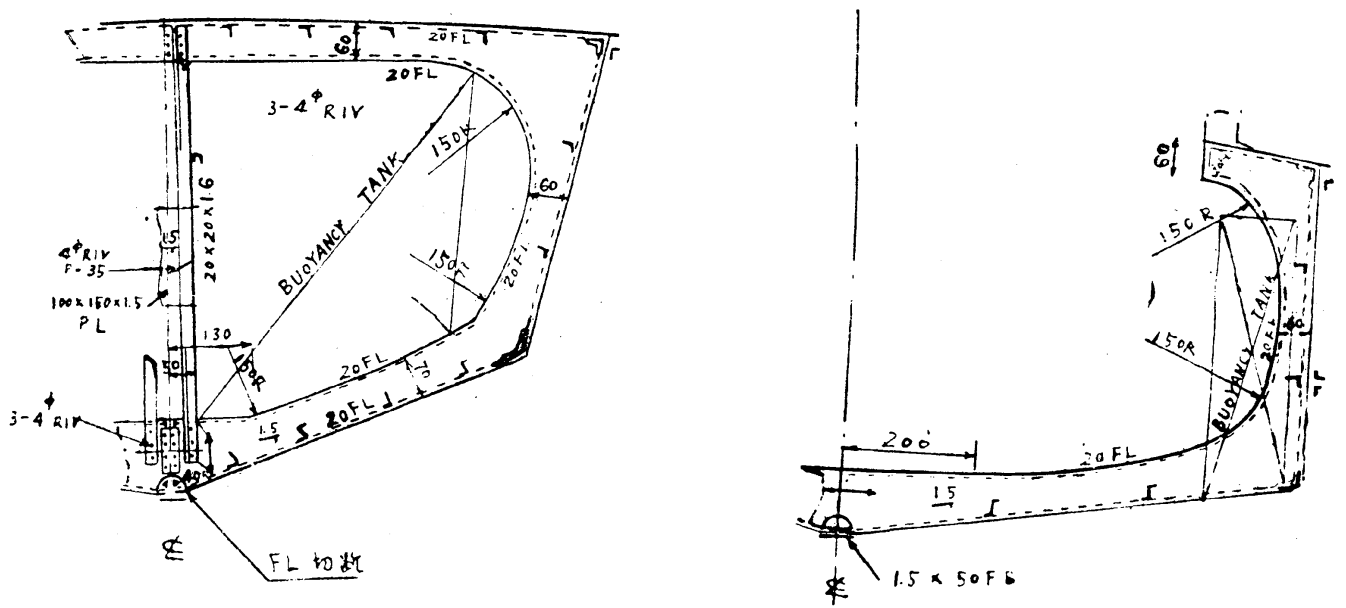

第 10 図䏚材 Fig. 10 Frame

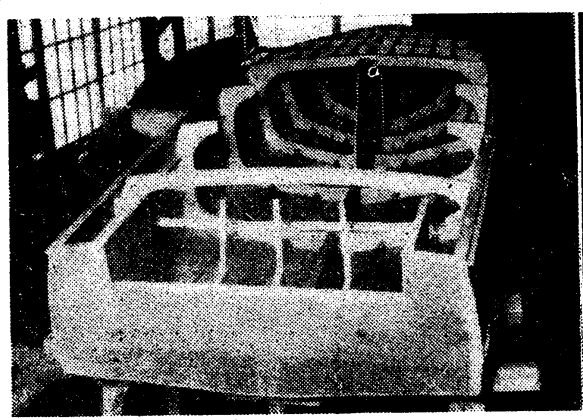

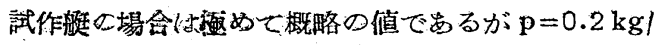

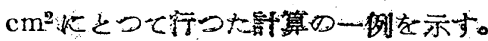

$\mathrm{t}=0.8 \mathrm{~mm}, 2 \mathrm{a}=120 \mathrm{~mm}, z z=150$

$\sigma_{\max }=18.23+1.92 \Rightarrow 20.15 \mathrm{~kg} / \mathrm{mm}^{2}$

$\mathrm{p}=0.2 \mathrm{k} / \mathrm{cm}^{2}$ の根抛は手許にむつたSnipe 型ヨットの

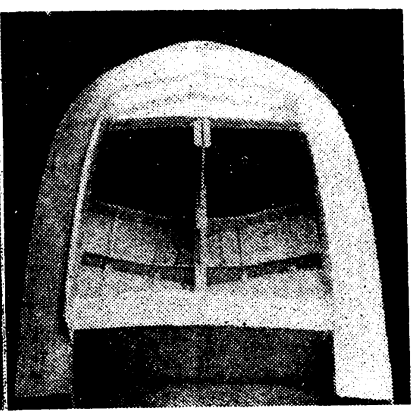

第11図(左) 肋材之緥通材 Fig. 11 Frame and Longi

\section{第12図(右)}

Fig. 12
構造図より適当に逆算したところ $\mathrm{p}=0.188 \mathrm{~kg} / \mathrm{cm}^{2}$ とた つたので採用した。しかし高速艇の場合はskimすると水 王中心はかなり後方へ移り，speedが早くたると艇底の らける動圼は可たり大きくなるのでstagnation point 附近の局部強度奻分注意を要する。 


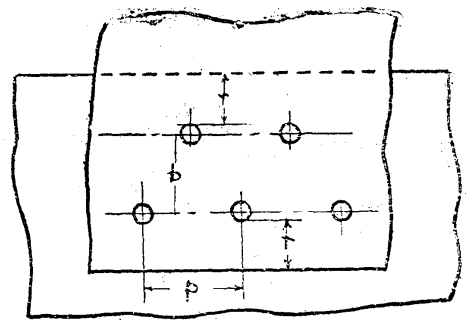

第 13 図 Fig. 13

\section{4. 構}

\section{造}

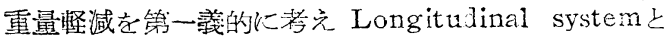
乙, 使用材㩽は $56 \mathrm{~S}-\mathrm{t} / 2 \mathrm{t} \mathrm{t}=0.8 \mathrm{~mm}, 1.5 \mathrm{~mm}, 56 \mathrm{~s}$

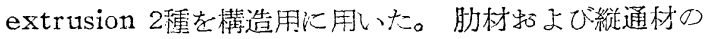
模様は第9,10図の構造図打よび写真牚11, 12図索参照さ れたい。

$\mathrm{t}=0.8 \mathrm{~mm}$ の板を用いた所依 shell plate, deck, keelson等で, $\mathrm{t}=1.5 \mathrm{~mm}$ の板孝用い、所はstem, keel, frame, gunwale, chine angle, breast, rail, wave breaker, center board trunk; stern pannel 等较 る。綎通材は EZB1116, ELB08160二種を用いた。

艇体棈造は涀在の段階では熔接には困難な点が多いの で鋲構造とした。鋲材は $56 \mathrm{~S} \mathrm{O}$ ○で，これより鋲を造り， 一般に0. $8 \mathrm{~mm} \times 1.5 \mathrm{~mm}$ Drivetに好 $3 \phi, 1.5 \mathrm{~mm} \times 1.5 \mathrm{~mm}$ の rivet に过4 4 を用いた。外板相互の結会は水密老確 実にするためジンククロメートをしませたガー妾を間に 《さ多， $\mathrm{p}=5 \mathrm{~d}, \mathrm{~b}=4 \mathrm{~d}, \mathrm{r}=3 \mathrm{~d}$ でジグザグに鋲を打つ た。(第13図)

特に艇底，艇側，甲板の表面は捏抗を小さくするため と外観它よくするために沈频鋲を打つた。

\section{I 作}

工作はすベて日本鋼管鶴見造船所で行われた。

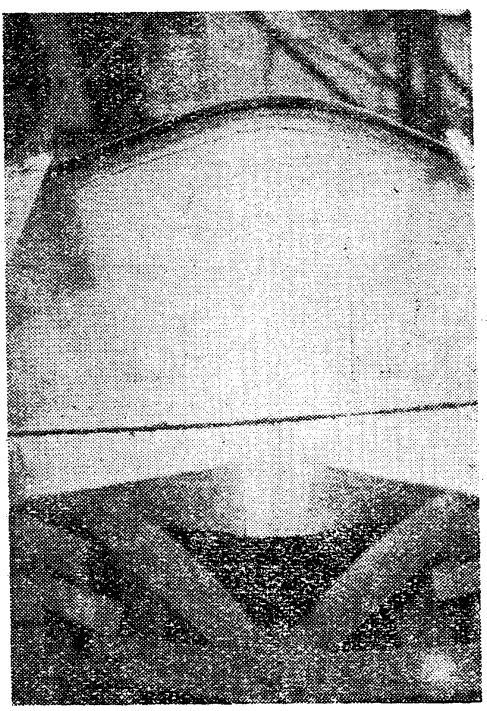

第 14 図艇首

Fig. 14 Stem

羁善ばベンガラをアラビャ䊪にといて用いた。 板の切断は㨁線剖はシャリング，屈線部はロータリー

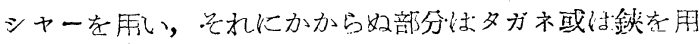
いた。型材の切断には鋸を用いた。

Flangingは最小内側半径が4 $\mathrm{t}$ 以下にたると触裂を

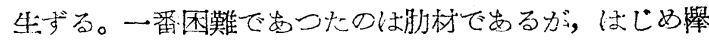
材の型で汀つたところ板耳㭁瑻にくいこむ僋向があるの

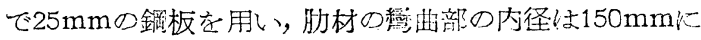
一定し，彎曲部之直線部之別々に下型をつくり，抑元金 其を用いで各 frameを製作した。bevelば一度 flange した後で䛯整した。

Stem材は bar stemにすれば临単で者るが, 注文材料

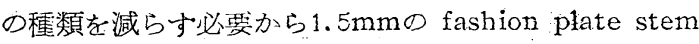
とした。相当大きた Couble curvatureが市り，製作が

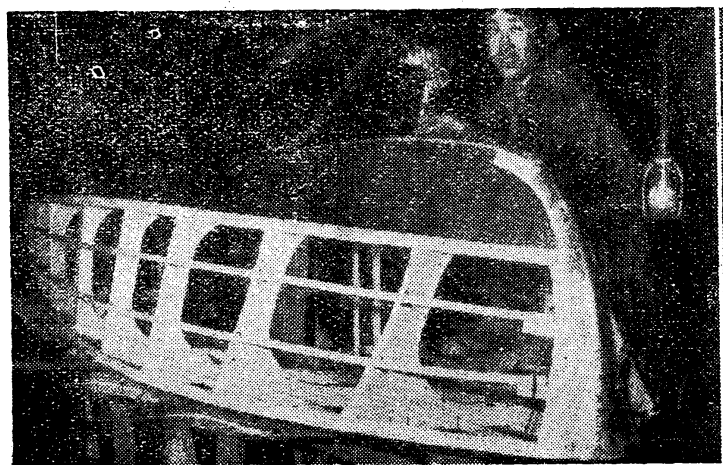

第 15 図 鉸 : 鋲 Fig. 15 Rivetting

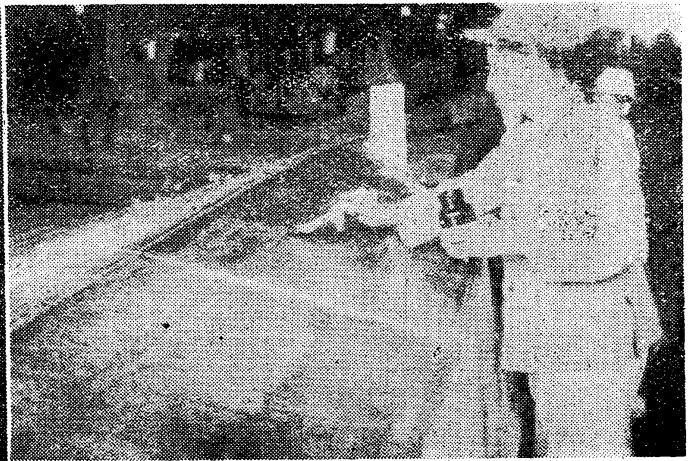

第16図、滁

Fig.16 Painting 


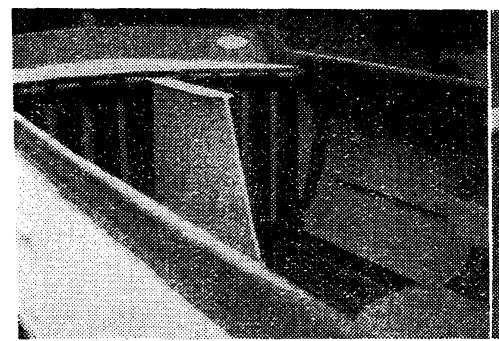

第 17 図コックピツト前部 Fig. 17 Fore part of Cockpit

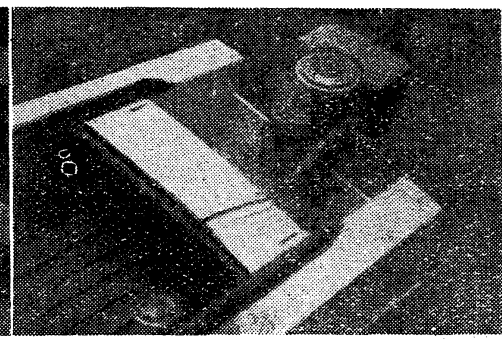

第 18 図コックピツト後部

Fig. 18 After part of Cockpit

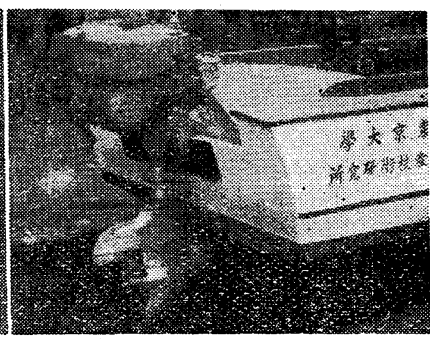

第 19図舷外機

Fig. 19 Out Eoard Engi ive
非常に困難で，いろいろ試不た後結局松材の内型を造り

\section{トーテランプで $300^{\circ} \mathrm{C}$ 程度に筫して加工した。}

縦通材力媩材を貫通する䇢所は肋材に孔を安け，肋材 の flange は切らず，縦通忉を板厚だけjoggleする。型 材は軟いので冷間でも北工できるが，ガストーチでちよ

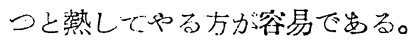

水此めの必要から艇呈 panel等に一部熔接を用いた。 熔接棒は友金或はアルミニウム低温答接棒, フラックス は大Eutector Flux No.190を用いた。 強度はたく単に 水止めで岁る。

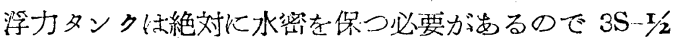
$\mathrm{H}, \mathrm{t}=1.0 \mathrm{~mm}$ 用心友金によつて全愹接をした。

沈頭鋲は例えば0.8mm之 $1.5 \mathrm{~mm}$ とを接合する場合下 の板に皿をとるのは勿論で岁るが，上の板にも厚み一杯 皿をとつてと行うと喰いこみがよく抜けにくい。孟の角度 は航空の方と同じく78 にとつた。鉸鋲は centre board trunkの horizontal stiffener 如く修理困難な所は且. とりの後入念に手かしめを汀つた。その他はエヤーハン マーを用い，鉸鋲数は約10,000本である。

水密試験は deck まで満水し (head䄪700mm)一日半 忋いたが漏水はたかつた。

塗装は素地表面をべンゾールで拭き，下虬処理として エッチプライマーを涂つたが，吹きつけとはけ涂りの䦵 方を用いた。下塗りにはジンククロメート，上塗りには フタール酸樹脂ェナメルを2回叙つた。色は

$\begin{array}{ll}\text { 艇底, レール, 波切り } & \text { コロンビアンブルー } \\ \text { 艇側 } & \text { ホワイト } \\ \text { 内部 } & \text { スタチックライトグリーン } \\ \text { 甲板 } & \text { ブラッシュバフ }\end{array}$

に淮りわけた。

製作に要した工数は約 600工数の由でもるが，これは 試作でめつたためと重量軽減を第一としたので工作が複 雑になつたためで, 重量軽減を幾分儀﨡にすれば相当程 度減少しうると考える。

\section{6. 艤装}

将来隹ヨットとしSnipe 型の㕨装を行ち予定でもるが
現在の段階では艤装は一部しか行つでいない。 木製艇では万一䫏覆した場合でも木材の浮力によつて

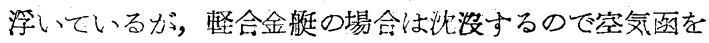
大れて孚力をもたせている。艇体，機関，艤䒾品の重量 结合訢 300kg以下之予想され，宾気函结前部 2 個，後部 4 個で計6個総学力 $412 \mathrm{~kg}$ (真水)，艇に浸水した場合任 臣水平以浮ぶ。材料は熔接を行らため3S- $1 / 2 \mathrm{H}, \mathrm{t}=1.0$ mmの板を用い，歪が多少出つたか门0.07 kg/ $\mathrm{cm}^{2}$ の耐圧 試験に合格した。破損の危険のむる部分，すなわち cockpit に面した部分には sparring を施した。

乘員か艇底を破らぬよう梄材の grating を敨いた。 艇が岸壁等に接触する際の摩耗，損傷を防ぐためDeck side line の下側括よび艇尾側面約 $1 \mathrm{~m}$ K $20 \times 18 \mathrm{~mm}$ 罪 材の fender をつけた。そのとりつけは上面は deck plate をのばし，下面は $0.8 \times 15 \times 15 L$ にビス止めをし た。艇尾則面のものは上下とも、記のアングルで止めた ヨットとして横漂流を防ぎ重心を下げるためのセンタ

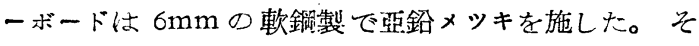
の他 oar clutch stay, jib seat fair leader 等に一部 鋼材を使用したがすざで監鉛メッキを施し，アルミ之の 接触面にばジンククロメートをガーゼにし杰せたる。を 梳さんで絶縁した。これはガルヴアニックアクションに よる筒触を防ぐためでめる。

クリート両舷各 3 個はヒドロナリウム系の鋳物を岉い 修轾打よび硫酸覆膜のアルマイト处理を行つた。これは 耐蝕性を比較する子定でする。

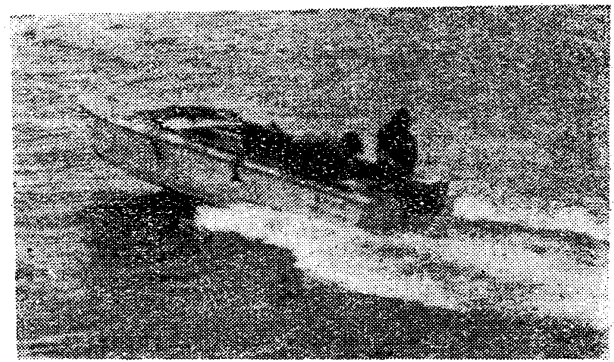

第 20 図全速力で滑走中 (27 ソット)

Fig. 20 Skimming with full speed(27knots) 


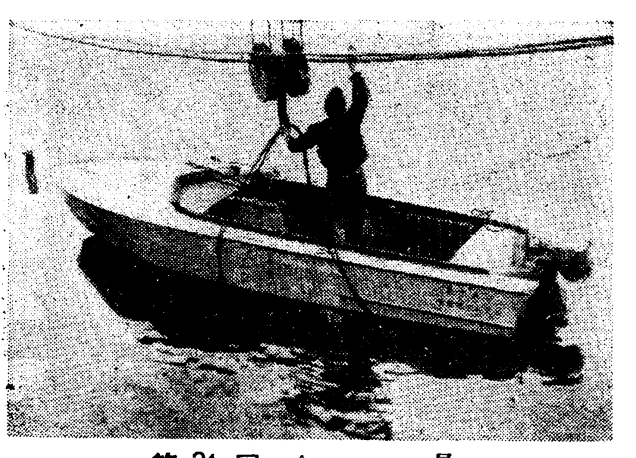

第 21 図 全 景

Fig. 21 Total view

艇底の涂水栓は銅系の合金で乷つたものであるが，ジ ンククロメートを2回染つだガーゼをはさみ特に注意し

へ取付计た。

\section{7・重量および速力の計測}

1952年 6 月25日完成艇の重量計測を行つたが総重量 $210 \mathrm{~kg}$ でその内訳は次の通りである。

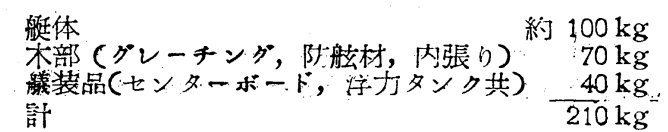

艇体 $100 \mathrm{~kg}$ はほほほ瓦型の木製艇に較べ約半分で，更に 木製艇が水汇莎ぶと水を吸つて重くたることを考えれば 軽合金製艇は非常に整くできることがわかる。

同年7月8日速西の阡測在行つた。使用機関はJohnson $22 \mapsto$ の航外機で回転数 $4000 \mathrm{rpm}$, 重量 $50 \mathrm{~kg}$, 平水で2 人乘艇 $(50 \mathrm{~kg} \times 2=100 \mathrm{~kg})$, 最大 27 ノットを出し，3人 乗艇 $(85+70+50=205 \mathrm{~kg})$, 鶴見:沖で波浪中 r $^{\prime} / 2$ マイル のマイルポストを2往復して訐測結果ば 17.18 ンットで めつた。

艇型がモーターボート専門にできていたいのでするが 予想以上の速力でむり，重量隇少の影響が可なりむると 考えられる。

\section{8. 後 記}

試作艇は艇殼重量約 $100 \mathrm{~kg}$ で予想ど抢り極めて軽い艇 ができた。試運転の結果も工作，強度，振動等に久陷を 認めたかつた。引统き精密た強度測定, 振動計測, 耐蝕 試験等を行う計画である。また帆装を招こなえば日本最 初の全アルミ合金製ヨットとたる予定である。

本艇の試作は昭和25年度文部省試験研究費をるとにし たもので岁るが，日本鋼管鶴見造船所が建造に絕大なる 御協力をされたために完成したもので梁甚なる感謝の意 を表する。使用材料について日本軽金属，神鋼金属，叙装 について関西ベイントの御妿力を樑く感謝すると共に, 御教示御協力⿺頂いた船舶用軽金属委員会，東大生研 AURC，旧第二工学部船舶教室の各位厚く御礼申上. げる。

$$
\begin{aligned}
(\mathrm{p} 12820 つ く & \\
\therefore \delta & =A \frac{r h P^{b}}{E p^{3}}
\end{aligned}
$$

板厚の小なる範用に於いては

$$
\begin{aligned}
& \delta^{\star}=A \frac{r h p}{E p t^{3}} \\
& \text { ( } A \text { : 常数) }
\end{aligned}
$$

\section{7 結 論}

7. 1 各板厚に対する撓夕と荷重の䦎保は，第1 報と 同様扰物線として示寸事が出来る。板厚の小さい範囲で は1つの抛物線であり，板厚が増加するにつれて2つの 物線で示される様になる。その限界は略 0.5 0.6mm 附近他ある様に思われる。

7. 2 各曲線の傾斜角は板厚 $t$ k比例し，結局撓み， と の関係は一般に

$$
\delta=A \underset{E p t^{3}}{r h p^{b}}
$$

で示され，板厚の薄い範围でば $\mathrm{b}$ は

略々 1 亿近く

$$
\delta=A_{E p t^{3}}^{V h p}
$$

$$
\delta=V \frac{V h p}{E p t^{3}}
$$

7. 3 板厚が約 $0.6 \mathrm{~mm}$ 以上にたると第 2 図に示寸如 き曲䠌とたり，飛躍現象を示す。此の原因に就いては更 に研究したいと思つている。

7.4第3図より第4図より $\mathrm{Al} の$ 合金に於いても (7. 2貢) k示寸関保式が同様成立するものと考方られ る。

7. 5 更に理論的解析に就いては時期を見て発表した 认と思つている。

\section{備考}

軽金属 No. 1 第1 報炘俱記及びミンズリントがある ので訂正する。

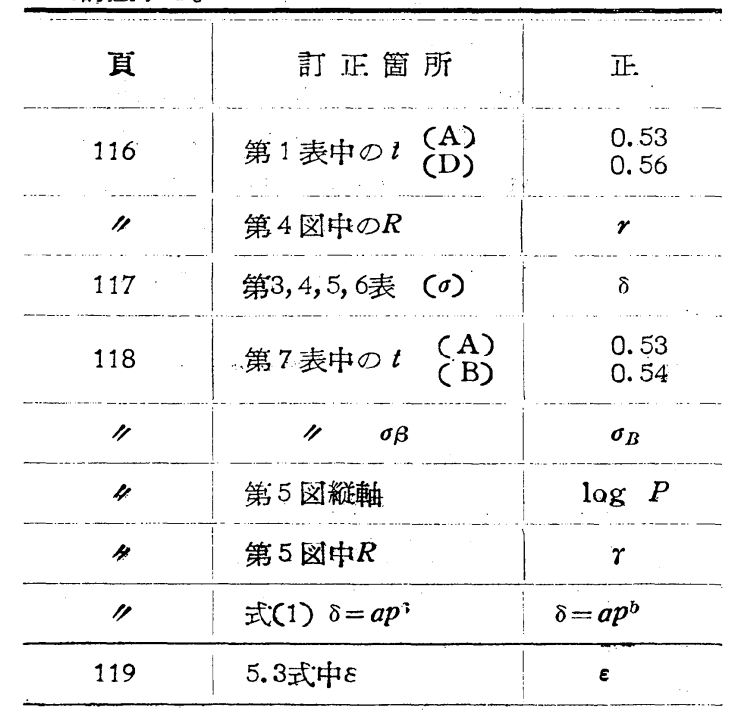

